\title{
PENERAPAN MEDIA GAMBAR LINGKUNGAN SEKITAR DALAM MENINGKATKAN KEMAMPUAN MENULIS KARANGAN DESKRIPSI DI SEKOLAH DASAR
}

\author{
Afifah Alawia \\ Institut Agama Islam Negeri Palopo \\ Jl. Agatis I, Balandai, Bara, Kota Palopo, Sulawesi Selatan 91914 \\ E-mail: afifah.alawia@email.com
}

\begin{abstract}
This study reveals the subject matter of the description essay writing skills with the application of environmental culture image media. This study aims to determine the improvement of writing essay descriptions that are applied through environmental culture image media in fourth grade students of SDN 009 Tarue, North Luwu Regency. This study uses a type of qualitative and quantitative approach with the type of Classroom Action Research (CAR) through two cycles. Data collection techniques are planning, action, observation, reflection. The research data obtained were analyzed using a descriptive statistical formula (percentage) to express descriptively the results of the study. From the results of the study it was found that at the precycle stage, the value of the results of the description essay writing skills of students with an average value was 5.860\%. After learning is done by applying image culture based on environmental culture, in the first cycle the value of students' essay writing skills with an average value is $6.720 \%$. Then, continued in the second cycle the value of the results of writing a description of students with an average value of $7.780 \%$. Thus, writing essay skills for fourth grade students at SDN 009 Tarue, North Luwu Regency by applying the image environment around the first cycle to the second cycle showed effective results. Therefore, environmental culture-based image media needs to be used as a reference by teachers in essay writing learning activities in elementary schools, especially SDN 009 Tarue North Luwu Regency.
\end{abstract}

Keywords: Media picture, essay description

\begin{abstract}
Abstrak
Penelitian ini mengungkapkan pokok permasalahan tentang keterampilan menulis karangan deskripsi dengan penerapan media gambar lingkungan sekitar. Penelitian ini bertujuan mengetahui peningkatan menulis karangan deskripsi yang diterapkan melalui media gambar lingkungan sekitar pada siswa kelas IV SDN 009 Tarue Kabupaten Luwu Utara. Penelitian ini menggunakan jenis pendekatan kualitatif dan kuantitatif dengan jenis Penelitian Tindakan Kelas (PTK) dengan melalui dua siklus. Teknik pengumpulan data yaitu perencanaan, tindakan, pengamatan, refleksi. Data penelitian yang diperoleh dinalisis dengan menggunakan rumus statistik deskriptif (persentasi) untuk mengungkapkan secara deskriptif hasil penelitian. Dari hasil penelitian ditemukan bahwa pada tahap prasiklus, nilai hasil keterampilan menulis karangan deskripsi siswa dengan nilai rata-rata adalah 5,860\%. Setelah dilaksanakan pembelajaran dengan menerapkan media gambar berbasis budaya lingkungan, pada siklus I nilai keterampilan menulis karangan siswa dengan nilai rata-rata adalah 6,720\%. Kemudian, dilanjutkan pada siklus II nilai hasil menulis karangan deskripsi siswa dengan nilai rata-rata adalah 7,780\%. Dengan demikian, keterampilan menulis karangan deskripsi siswa kelas IV SDN 009 Tarue Kabupaten Luwu utara dengan penerapkan media gambar lingkungan sekitaryang dimulai dari siklus pertama sampai siklus ke-2 menunjukkan hasil yang efektif. Oleh karena itu, media gambar lingkungan sekitar perlu dijadikan referensi oleh guru dalam kegiatan pembelajaran menulis karangan di sekolah dasar, khususnya SDN 009 Tarue Kabupaten Luwu Utara.
\end{abstract}

Kata Kunci,: Media gambar, Karangan deskripsi. 


\section{PENDAHULUAN}

Pembelajaran bahasa Indonesia pada jenjang SD/MI, ada ada 4 komponen yang terdapat dalam kemampuan berbahasa dan kemampuan dalam bersastra diantaranya, mendengarkan, berbicara, membaca, dan menulis (Zulela, 2013: 5). Keterampilan-keterampilan tersebut erat hubungannya dengan proses yang mendasari bahasa. Bahasa adalah bentuk implementasi pikiran seseorang. keterampilan berbahasa searah dengan jelasnya jalan pikiran seseorang. Salah satu cara untuk memperoleh keterampilan yaitu dengan memperbanyak latihan, karena dengan adanya latihan maka, keterampilan dapat diperoleh. Dalam melatih keterampilan berbahasa sama halnya dengan melatih keterampilan berpikir. Bahasa Indonesia perlu diterapkan kepada siswa di sekolah dasar untuk mempertajam kepekaan perasaan siswa, melatih kreativitas berpikir, dan daya khayal serta berkomunikasi dengan baik. Salah satu keterampilan yang akan dipelajari pada jenjang pendidikan sekolah dasar ialah keterampilan menulis yang merupakan keterampilan yang paling utama.

Pada hakikatnya manfaat bahasa adalah sebagai media dalam berkomunikasi. Bahasa memiliki peran sebagai pusat dalam perkembangan afektif, kognitif, dan psikomotorik siswa dan menjadi tolak ukur keberhasilan dalam memahami berbagai bidang studi. Pembelajaran bahasa diharapkan bertujuan membantu siswa dalam mengenal dirinya, budayanya, dan budaya orang lain, mengemukakan gagasan dan perasaan, ikut serta dalam masyarakat yang menggunakan bahasa tersebut, dan menemukan serta menggunakan kemampuan menganalisa dan mengimajinasikan yang ada dalam dirinya (Depdiknas, 2008:105). Pembelajaran bahasa berbasis multikultural memberikan pemahaman kepada pendidik dan peserta didik akan kebudayaan daerah setempat sehingga mampu beradaptasi dengan daerah sekitar (Rustan, 2010).

Keterampilan menulis sebagai salah satu dari keempat aspek keterampilan yang merupakan kegiatan produktif dan ekspresif. Menulis adalah suatu proses dalam penyampaian ide, informasi, sikap, dan argumen kepada pembaca dengan lambang bahasa untuk mencapai maksud dan tujuan. Dengan demikian, mengarang atau menulis merupakan aktivitas menuang kan ide/gagasan ke dalam sebuah karya tulis dengan tujuan tertentu yang biasa dituangkan dalam bentuk tulisan maupun lisan. Namun, untuk menggambarkannya dalam bentuk tulisan yang teratur tidaklah mudah, banyak orang yang mampu bercerita tentang hal yang a da dalam pikirannya, tetapi belum mampu menggambarkannya dalam bentuk tulisan. Masalah yang sering ditemukan dalam pelajaran mengarang adalah siswa kurang mampu menguasai pemakaian bahasa Indonesia yang baik dan benar. Kesalahan dalam penggunaan kosa kata, tanda baca dan struktur kalimat menyebabkan keambiguan kalimat sehingga timbul kesalahan dalam penalaran kalimat (Rustan, 2016). Hal ini dapat terjadi pada pembelajaran siswa sekolah dasar yang kemampuannya dalam menulis karangan masih kurang dan bahkan ada yang tidak tahu sama sekali. Kondisi ini menunjukkan bahwa proses belajar bahasa Indonesia di sekolah masih mengalami kualitas rendah, akhirnya siswa

PiJIES: Pedagogik Journal of Islamic Elementary School 
tidak terampil dalam berpikir dan berbahasa. Dengan demikian, tugas yang diberikan tidak akan selesai atau hasilnya tidak seperti yang diharapkan.

Peran guru sangat penting, bukan hanya harus menguasai meteri ajar. Melainkan juga harus memiliki dan menguasai teknik pembelajaran, agar dapat dilaksanakan sesuai dengan tujuan yang akan dicapai dengan menggunakan alat peraga, seperti media gambar yang sesuai dengan materi ajar sehingga dapat tercipta proses pembelajaran yang tepat, efektif, dan efisien (Hasmira, 2018). Keterampilan berbahasa terdiri atas empat komponen, yaitu keterampilan menyimak, berbicara, membaca dan menulis. Keempat keterampilan tersebut, satu sama lain tidak dapat dipisahkan karena merupakan satu kesatuan. Salah satu upaya yang akan dilakukan untuk meningkatkan keterampilan menulis deskripsi pada siswa yaitu dengan memanfaatkan media lingkungan sekitar sebagai media pembelajaran dalam pembelajaran. Dengan demikian diharapkan akan lebih menarik dan tidak membosankan bagi siswa sehingga dapat menuangkan ide dan mengungkapkan perasaanya dalam bentuk deskripsi.

Menulis adalah kegiatan penyampaian pesan dengan menggunakan bahasa tulis sebagai alat atau medianya (Idarliati, 2018). Pesan adalah isi atau muatan yang terkandung dalam suatu tulisan. Tulisan merupakan sebuah simbol atau lambang bahasa yang dapat dilihat dan disepakati pemakaiannya. Menulis bukanlah suatu yang asing bagi kita. Artikel, esai, laporan, resensi, karya sastra, buku, komik, dan cerita adalah contoh bentuk dan produk bahasa tulis yang akrab dengan kehidupan. Tulisan itu menyajikan secara runtut dan menarik, ide, gagasan, dan perasaan penulisnya (Sukirman, 2015: 3). Sedangkan menurut pengestu dalam dalam buku solchan dkk pembelajaran menulis diharapkan mampu mengarahkan siswa ke usaha pengembangan sumber dayanya dan menjadikan pembelajaran menulis lebih bermakna berharga bagi siswa. Selanjutnya diharapkan dapat mengantarkan siswa menjadi penulis dan pemikir yang baik, serta mandiri (Solchan dkk, 2014: 734).

Menulis merupakan suatu keterampilan berbahasa yang gunakan untuk berkomunikasi secara tidak langsung. Dalam kegiatan menulis, penulis harus terampil memanfaatkan struktur bahasa dan kosakata. Keterampilan ini tidak akan datang secara otomatis, tetapi harus melalui latihan dan praktek yang banyak dan teratur (Nurhadi, 2010: 214). Kemampuan menulis merupakan kemampuan dalam menyampaikan pesan kepada pihak lain secara tertulis. Kemampuan ini bukan hanya berkaitan dengan kemahiran siswa dalam menyusun dan menulis karangan, melainkan juga menyatakan pikiran, pendapat, sikap, dan perasaannya secara jelas dan bertahap sehingga dapat dipahami oleh orang yang membacanya.

Berdasarkan kelima pengertian tersebut dapat dipahami kemampuan menulis merupakan kemampuan dalam menuangkan gagasan dalam bentuk bahasa tulis dengan tujuan memberitahu, atau menyakinkan sehingga dapat dipahami yang menerimanya. Beberapa tujuan menulis di antaranya adalah: Tulisan yang memberitahukan suatu informasi, Tulisan yang meyakinkan atau mendesak, Tulisan yang menghibur atau menyenangkan, Tulisan yang mengekspresikan perasaan dan emosi yang kuat. 
Adapun yang menjadi Faktor hambatan dalam kegiatan menulis, yaitu faktor internal adalah faktor hambatan atau tantangan yang berasal dari dalam diri sendiri, misalnya belum mempunyai kebiasaan membaca buku, belum memiliki kemampuan berbahasa yang baik,belum ada minat untuk menulis, belum ada rasa percaya diri menulis, belum ada mood menulis. sedangkan faktor eksternal adalah faktor hambatan atau tantangan yang berasal dari luar diri siswa, misalnya kesulitan menemukan bahan tulisan (referensi), kesulitan menemukan topik tulisan, kesulitan memahami teknik menulis karya ilmiah. Karangan deskripsi merupakan salah satu jenis karangan yang harus dikuasai oleh siswa. Karangan ini sudah dapat diperkenalkan sejak SD kelas IV. Oleh karena itu, siapa pun yang menjadi guru mata pelajaran Bahasa Indonesia harus menguasai materi tentang karangan deskripsi.

Karangan deskripsi adalah suatu tulisan atau karangan yang menggambarkan atau memaparkan suatu objek, lokasi, keadaan atau benda dengan kata-kata secara jelas. Biasanya hal yang digambarkan dalam karangan tersebut merupakan hasil pengamatan pancaindra kita. Secara garis besar ada dua macam bentuk karangan deskripsi yaitu, Deskripsi Ekspositori Merupakan karangan yang sangat logis, biasanya merupakan daftar rincian atau hal yang penting-penting saja yang disusun menurut sistem dan urutan logis objek yang diamati. Deskripsi Impresionatis Merupakan karangan yang menggambarkan impresi penulisnya, atau untuk menetralisir pembacanya. Deskripsi impresionatis ini lebih menekannkan impresi atau kesan penulisnya ketika melakukan impresi tersebut. Karangan deskripsi memiliki ciri-ciri seperti: Menggambarkan atau melukiskan sesuatu, penggambaran tersebut dilakukan sejelas-jelasnya dengan melibatkan kesan indera, membuat pembaca atau pendengar merasakan sendiri atau mengalami sendiri ( Firman, 2015: 29-30) .Berdasarkan pengertian tersebut, dapat dipahami bahwa karangan deskripsi adalah karangan yang mengungkapkan atau menggambarkan objek yang sedang diamati, dibicarakan dengan maksud untuk menciptakan imajinasi pembaca yang seolah-olah kejadian tersebut dialaminya sendiri, pembaca melihat sendiri objek tersebut. Salah satu pendekatan pembelajaran yang dapat merangsang siswa untuk menigkatkan kemampuan menulis karangan deskripsi, yaitu dengan menggunakan media gambar. Dalam hal ini, peran guru hanya sebagai motivator dan pengaruh proses pembelajaran bahasa indonesia kelas IV.

Dalam proses belajar mengajar dengan adanya media mempunyai arti yang cukup penting. Karena dalam kegiatan tersebut ketidakjelasan bahan yang disampaikan oleh guru dapat dibantu dengan manghadirkan media sebagai perantara, kerumitan bahan yang disampaikan kepada peserta didik dapat memudahkan pembelajaran dengan bantuan media. Media dapat mewakili hal yang kurang mampu guru ucapkan melalui kata-kata atau kalimat tertentu, bahkan keabstrakan bahan dapat dimaksimalkan dengan kehadiran media. Dengan demikian, peserta didik lebih mudah mencerna bahan dari pada tanpa bantuan media. Kata media berasal dari bahasa Latin dan merupakan bentuk jamak dari kata medium yang secara harfiah berarti

PiJIES: Pedagogik Journal of Islamic Elementary School 
perantara atau pengantar. Medeo adalah perantara atau pengantar pesan dari pengirism kepenerima pesan (Arief S.Sadiman, dkk, 2012 : 2). Dengan kata lain, media merupakan aspek sumber belajar atau wahana fisik yang mengandung materi instruksional di lingkungan siswa yang dapat merangsang siswa untuk belajar (Azhar Arsyad, , 2015: 4). Sebagai alat bantu, media mempunyai fungsi melancarkan tercapainya tujuan pembelajaran. Hal ini dilandasi dengan keyakinan bahwa proses belajar mengajar dengan bantuan media mempertinggi kegiatan belajar anak didik dalam tenggang waktu yang cukup lama (Syaiful Bahri Djamarah, Aswan Zain, 2002: 138). Berdasarkan kamus besar Bahasa Indonesia, gambar adalah tiruan barang (orang, binatang, tumbuhan dan sebagainya). Gambar merupakan media visual dua dimensi diatas bidang yang tidak transparan. Guru dapat menggunakan gambar untuk memberi gambaran tentang pelajaran yang dibahas sehingga penjelasannya lebih konkret daripada diuraikan dengan kata-kata. Melalui gambar, guru dapat menerjemahkan ide-ide absrak dalam bentuk yang lebih realistik (Subana, dkk,322). Media Gambar dapat membantu guru dalam mencapai tujuan pembelajaran, karena dengan menggunakan media gambar termasuk media yang mudah dan murah serta besar artinya untuk mempertinggi nilai pengajaran. Karena dengan menggunakan media gambar, pengalaman peserta didik menjadi lebih luas, lebih jelas dan tidak mudah dilupakan, serta lebih konkret dalam ingatan dan asosiasi peserta didik (Ahmad Rohani, 1997: 76).

Gambar yang diberikan kepada siswa merupakan bagian dari kearifan lokal. Kearifan lokal pertama kali dikenalkan oleh HG. Quaritch Wales yang menyebut kearifan lokal sebagai "local genius" (Irwan Abbas, 2013: 276). Kearifan lokal setiap daerah berbeda, di kawasan Sulawesi Selatan memiliki banyak etnis dan suku-suku yang memiliki aneka ragam budaya dan kearifan lokal. Suku di Sulsel ada empat yaitu Bugis, Makassar, Toraja, dan Mandar (Erman syarif, dkk., 2016:15).

Dalam lingkungan sekitar terdapat berbagai tingkah laku dan kegiatan anggota masyarakat, kegiatan tersebut bisa berupa permainan dan kebiasaankebiasaan sehari-hari mereka yang didaerah lain belum tentu melakukannya. Apabila dibawa dalam persoalan belajar mengajar maka kearifan lokal dapat dijadikan sebagai salah satu media pembelajaran dalam dunia pendidikan. Dalam jenjang pendidikan dasar khususnya pelajaran mengarang siswa akan lebih senang jika diterapkan media yang mudah mereka maknai dan dapat merangsang ide dan daya khayalnya. Dalam penelitian ini peneliti menggunakan media gambar lingkungan sekitar dalam meningkatkan keterampilan menulis karangan deskripsi siswa, oleh karena itu penelitian ini bertujuan untuk mengetahui peningkatan hasil belajar siswa dalan kemampuan menulis karangan deskripsi dengan menggunakan media gambar berbasis lingkungan pada siswa kelas IV SDN 009 Tarue Kabupaten Luwu Utara. 


\section{METODE PENELITIAN}

Metode adalah suatu cara yang dipergunakan untuk mencapai tujuan yang telah ditetapkan. Dalam proses interaksi belajar mengajar motode diperlukan seorang guru bervariasi sesuai dengan tujuan yang telah dicapai setelah pengajaran berakhir, Objek tindakan dalam penelitian ini adalah penerapan media gambar lingkungan sekitar dalam meningkatkan kemampuan menulis Karangan Deskripsi Pada Siswa Kelas IV SDN 009 Tarue Kabupaten Luwu Utara, Penelitian ini adalah penelitian tindakan kelas (PTK) yang akan dilakukan secara bersiklus. Penelitian ini terdiri dari dua siklus, masing-masing siklus terdiri dari empat tahap yaitu (1) perencanaan (planing), (2) tindakan (acting), (3) observasi (observing), dan (4) refleksi (reflecting).

Untuk mengetahui keefektifan suatu metode dalam kegiatan pembelajaran perlu diadakan analisa data. Pada penelitian ini menggunakan teknik analisis deskriptif kualitatif, yaitu suatu metode penelitian yang bersifat menggambarkan kenyataan atau fakta sesuai dengan data yang diperoleh dengan tujuan untuk mengetahui prestasi belajar yang dicapai siswa juga untuk memperoleh respon siswa terhadap kegiatan pembelajaran serta aktivitas siswa selama proses pembelajaran. Subjek penelitian adalah kelas IV SDN 009 Tarue, tahun ajaran 2018/2019 dengan jumlah 25 siswa, untuk mengumpulkan data dalam penelitian ini dilakukan dengan observasi, tes dan dokumentasi.

\section{HASIL PENELITIAN}

\section{Penggunaan Media Gambar Lingkungan Sekitar pada Siswa}

Penelitian tindakan kelas dengan menerapkan media gambar pada mata pelajaran bahasa Indonesia yang dilakukan dalam dua siklus didapatkan data bahwa siswa kelas IV SD Negeri 009 Tarue Kabupaten Luwu Utara dapat menuntaskan KKM menulis deskripsi karangan dengan baik dengan perolehan nilai rata-rata mencapai $77,80 \%$. Hal ini dapat dilihat dari peningkatan hasil belajar siswa mulai dari nilai awal siswa, siklus I dan siklus II.

Hal-hal yang dilakukan adalah: Menentukan materi yang akan diajarkan, Membuat Rencana Pelaksanaan Pembelajaran (RPP), Membuat lembar observasi aktivitas siswa untuk melihat peningkatan hasil belajar siswa, membuat lembar observasi aktivitas guru untuk melihat perubahan belajar siswa, Menyusun tes evaluasi tentang materi yang telah diajarkan.

Pelaksanaan pembelajaran dengan pemanfaatan lingkungan sekitar sebagai sumber belajar untuk meningkatkan keterampilan menulis deskripsi terdiri dari beberapa tahap, yaitu, tahap perencanaan, tahap pelaksanaan, tahap observasi, serta tahap refleksi. Dalam tahap perencanaan, hal yang dilaksanakan guru adalah mengidentifikasi masalah, menganalisis standar kompetensi dan kompetensi dasar, menyusun RPP, menyiapkan media

PiJIES: Pedagogik Journal of Islamic Elementary School 
pembelajaran, mengembangkan LKS dan menyusun instrumen penelitian. Setelah tahap perencanaan dilakukan, kemudian dilanjutkan dengan tahap pelaksanaan tindakan dan observasi. Observasi, pada tahap ini untuk mengetahui proses pembelajaran yang dilakukan dan aktivitas siswa dalam kegiatan pembelajaran dengan menggunakan lembar observasi peneliti dan yang menjadi sasaran observasi peneliti yaitu aspek kognitif. Data hasil penelitian kognitif (pengamatan) dilakukan untuk siswa, dan indikator aspek proses pembelajaran yang dilakukan guru dalam kegiatan pembelajaran sesuai dengan instrumen pengamatan. Apsek-aspek proses pembelajaran yang dilakukan guru meliputi perencanaan, kegiatan utama, dan pemantapan. Hubungan stimulus dan respons ini, jika diulang dapat menjadi sebuah kebiasaan. Pengulangan informasi yang diberikan kepada anak menjadikan informasi tersebut lebih mudah untuk diserap oleh anak-anak dikarenakan leksikon anak lebih rapi dan terstruktur dibandingkan orang dewasa (Rustan \& Subhan, 2018).

Refleksi dilakukan untuk mengetahui kekurangan atau kendala siklus I. Pelaksanaan pada siklus I dapat dikatakan cukup baik, namun masih ada beberapa kendala. Kendala yang dimaksud adalah: Siswa masih kurang aktif dalam menyampaikan pendapat dan kurang menjawab pertanyaan, siswa masih kurang memperhatikan pelajaran pada saat guru sedang menjelaskan. Melihat kendala-kendala tersebut maka perlu dilakukan tindakan perbaikan agar hasil pembelajaran pada siklus II bisa lebih optimal. Usaha membentuk kecakapan dalam diri peserta didik guna mencapai tujuan pendidikan, perlu peningkatan kinerja guru sebagai tenaga pengajar. Kegiatan pembelajaran yang akan dilaksanakan pada siklus II cara mengajar guru akan ditingkatkan secara lebih baik dengan mengacu kepada kelemahan-kelemahan yang terjadi pada siklus I.

\section{Motivasi belajar siswa dapat di tingkatkan dengan penggunaan media gambar lingkungan sekitar.}

Aktivitas pembelajaran dilakukan bertujuan untuk meningkatkan keberhasilan belajar siswa setelah mengalami proses pembelajaran. Salah satu upaya yang dilakukan untuk mencapai keberhasilan pembelajaran agar efektif dan efesien, yakni penggunaan metode pembelajaran yang sesuai dengan materi yang diajarkan. Dalam mengajarkan mata pelajaran bahasa Indonesia khususnya pada materi penerapan media gambar berbasis budaya lingkungan dalam meningkatkan kemampuan menulis karangan deskripsi dibutuhkan metode yang membantu siswa memahami konsep dan bacaan-bacaan dengan baik dan benar. Oleh karena itu, penggunaan media gambar diharapkan mampu memberi pengetahuan dan pemahaman lebih bagi siswa melalui pengalaman langsung penerapan media gambar adalah metode pemberian kesempatan kepada siswa perorangan atau kelompok untuk dilatih melakukan suatu pembuktian kebenaran berupa gambar. Dengan penerapan media gambar pembelajaran akan lebih efektif.

Sesuai dengan teori tersebut penelitian tindakan kelas dengan menerapkan media gambar pada mata pelajaran bahasa Indonesia yang dilakukan dalam dua siklus didapatkan data bahwa siswa kelas IV SD Negeri 009 Tarue Kabupaten Luwu Utara dapat menuntaskan KKM menulis deskripsi 
karangan dengan baik dengan perolehan nilai rata-rata mencapai 77,80\%. Hal ini dapat dilihat dari peningkatan hasil belajar siswa mulai dari nilai awal siswa, siklus I dan siklus II.

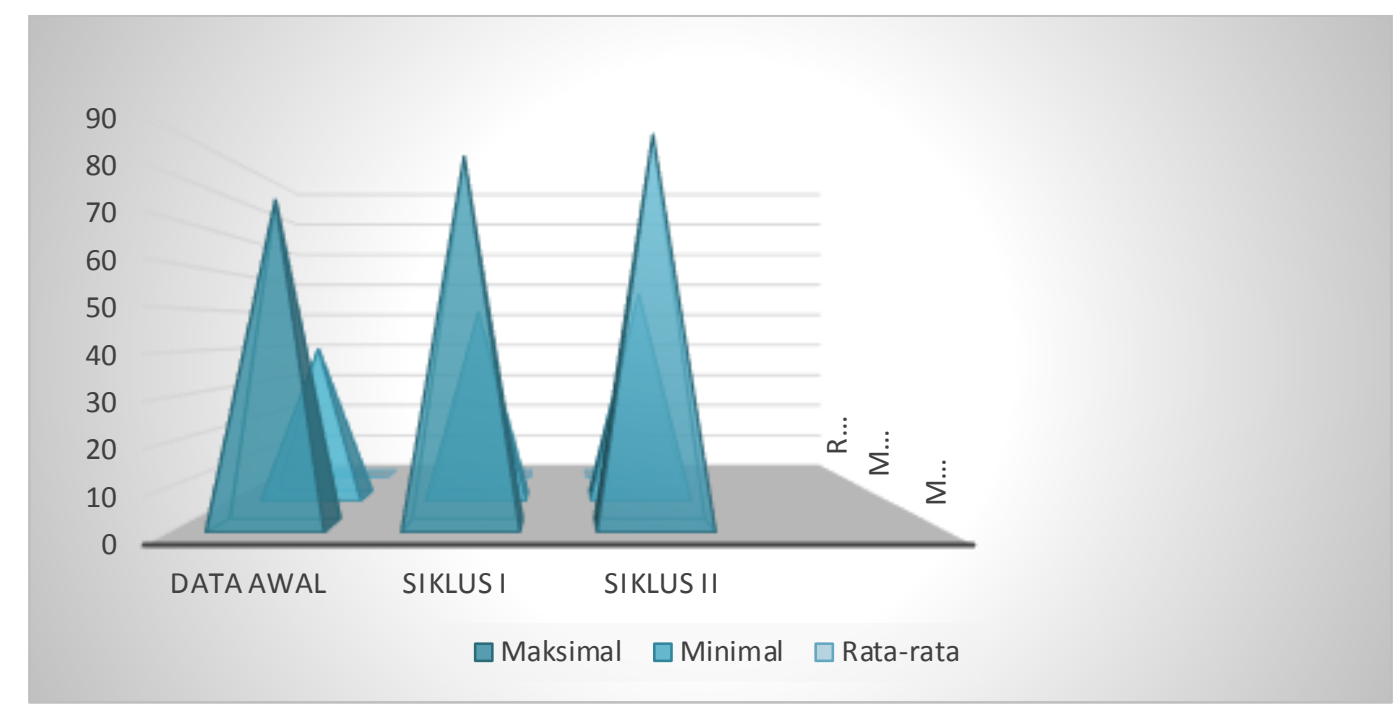

Berdasarkan pada gambar diagram diatas dapat dipahami adanya peningkatan hasil belajar siswa dari setiap siklus, yaitu data awal siswa memperoleh nilai rata-rata 58,60, pada siklus I nilai rata-rata siswa 67,20, dan pada siklus II nilai rata-rata siswa mencapai 77,80. Dengan demikian dapat disimpulkan bahwa media gambar lingkungan sekitar mampu meningkatkan hasil belajar siswa pada mata pelajaran bahasa Indonesia materi karangan deskripsi siswa kelas IV SD Negeri 009 Tarue Kabupaten Luwu Utara semester 1 tahun ajaran 2018/2019.

Deskrpsi siklus I dilaksanakan selama 3 kali pertemuan, dengan 2 kali tatap muka dan 1 kali evaluasi dipertemuan akhir siklus. hasil evaluasi siklus I dari 25 siswa yang ikut dalam tes ternyata hanya 11 siswa yang memenuhi standar ketuntasan dengan nilai KKM yaitu 70 dengan ketuntasan belajar $44,00 \%$, dan 14 mendapat nilai $\leq 70$ dengan ketidaktuntasan 56,00\% dengan nilai rata-rata 67,20 .

Deskrpsi siklus II dilaksanakan selama 3 kali pertemuan, dengan 2 kali tatap muka dan 1 kali evaluasi dipertemuan akhir siklus. hasil keterampilan menulis karangan deskripsi siklus II, dari 25 siswa yang ikut dalam tes ternyata 24 siswa memenuhi standar ketuntasan dengan nilai KKM yaitu 70 dengan ketuntasan belajar $96,00 \%$ dan 1 orang mendapat nilai $\leq 70$ dengan ketidaktuntasan belajar 4,00\% dengan nilai rata-rata 77,80.

\section{PEMBAHASAN}

Berdasarkan hasil penelitian yang dilakukan di SDN 009 Tarue Kabupaten Luwu Utara dalam pembelajaran menulis karangan deskripsi menggunakan media gambar lingkungan sekitar mengalami peningkatan. Hal ini dapat dilihat dari hasil tes menulis karangan deskripsi siswa dari prasiklus, suklus I, dan siklus II.

PiJIES: Pedagogik Journal of Islamic Elementary School 
Sebelum melaksanakan penelitian dengan menerapkan media gambar lingkungan sekitar dalam meningkatkan kemampuan menulis karangan deskripsi pada siswa maka terlebih dahulu peneliti mengambil nilai hasil belajar siswa pada guru mata pelajaran bahasa Indonesia sebagai perbandingan hasil belajar prasiklus, siklus I, dan siklus II.

Berdasarkan kriteria hasil belajar mengenai katuntasan kelas, yaitu $96 \%$ data hasil penelitian pada siklus II di atas dianggap tuntas kelas dimana yang tuntas mencapai 24 dari 25 siswa. Penelitian ini tidak perlu dilanjutkan pada siklus berikutnya karena berdasarkan tujuam yang ingin dicapai, yaitu peningkatan hasil belajar sudah terlihat, maka peneliti mengaggap penelitian ini sudah cukup, dengan menyimpulkan bahwa terdapat peningkatan kemampuan menulis karangan deskripsi dengan menggunakan media gambar lingkungan sekitar pada siswa kelas IV SDN 009 Tarue Kabupaten Luwu Utara.

Berdasarkan hasil penelitian tampak bahwa penggunaan media gambar lingkungan sekitar memiliki pengaruh dalam meningkatkan keterampilan menulis karangan deskripsi siswa kelas IV SDN 009 Tarue Kabupaten Luwu Utara. Dari hasil analisis yang diperoleh, cukup mendukung teori yang telah dikemukakan Hamalik bahwa media pembelajaran dalam proses belajar mengajar dapat membangkitkan keinginan dan minat yang baru, membangkitkan motivasi dan rangsangan kegiatan belajar, dan bahkan membawa pengaruh-pengaruh psikologi terhadap siswa. Penggunaan media pembelajaran pada tahap orientasi pembelajaran sangat membantu keefektivan proses pembelajaran dan penyampaian pesan dan isi pelajaran pada saat itu. Selain membangkitkan minat dan motivasi siswa, media pembelajaran juga dapat membantu siswa menigkatkan pemahaman, memperoleh data yang menarik dan terpercaya, memudahkan penafsiran data, dan mendapatkan informasi (Ashar Arsyat 2013:19). Purwanto dan Alim (2007: 63) mengemukakan bahwa "penggunaan media gambar dapat melatih anak dalam menentukan pokok pikiran yang mungkian akan menjadi karangan-karangan". Guru dalam menyampaikan materi pelajaran hendaknya menggunakan media pendidikan yang menarik dan membantu pemahaman siswa. Selama ini guru terkesan dalam menyampaikan materi pelajaran lebih senang dengan menggunakan metode ceramah yang kurang menarik bagi siswa (Budiyanto 2009). Menurut Rahyono, kearifan lokal merupakan kecerdasan manusia yang dimiliki oleh kelompok etnis tertentu yang diperoleh melalui pengalaman masyarakat (Ulfah Fajarini, 2014:124). Artinya gambar yang diterapkan sebagai media pembelajaran hendaknya merupakan pengalaman siswa itu sendiri sehingga lebih mudah dalam memaknai media yang diberikan.

Penerapan media gambar berbasis budaya lingkungan tersebut memberikan pengaruh posotif terhadap proses pembelajaran siswa dalam menulis karangan deskripsi, karena siswa lebih mampu mamahami materi dengan mennggunakan media berbasis budaya lingkungan, dan siswa lebih mengekspresikan diri terhadap lingkungan. Dengan demikian sudah saatnya melakukan perubahan sistem pembelajaran dari cara konvensional menjadi pembelajaran dengan memanfaatkan lingkungan sebagai media pembelajaran. Proses belajar mengajar di dalam kelas tidak selamanya efektif 


\section{6 | Afifah Alawia}

tanpa adanya alat peraga sebagai pengalaman pengganti yang dapat memperkuat pemahaman siswa terhadap materi pelajaran yang di berikan. Akan tetapi, minimnya alat peraga menyebabkan guru perlu menanamkan materi, sedangkan lingkungan sekitar cukup potensial dijadikan media pengajaran sebagai pengalaman langsung yang tidak begitu saja dilupakan oleh siswa, karena lingkungan tersebut mudah untuk diketahui siswa.

Pengembangan keterampilan mengenal media gambar merupakan suatu usaha untuk meningkatkan kemampuan menulis karangan deskripsi pada siswa yang merupakan awal dari pembelajaran bahasa Indonesia agar baik dan benar. Seperti mengetahui bentuk media gambar dan sebagainya.

Dalam proses pembelajaran tersebut guru harus mempunyai metode yang bervariasi dalam pelajaran bahasa Indonesia, khususnya pembahasan mengajarkan siswa dengan menggunakan media gambar (visual) lingkungan sekitar, memperkenalkan media gambar secara sekaligus, menggunakan bahasa Indonesia dan sebagainya.

\section{PENUTUP}

Berdasarkan hasil penelitian yang diperoleh dan dianalisis dapat disimpulkan bahwa penggunaan media gambar dapat meningkatkan keterampilan menulis karangan deskripsi siswa. Hal itu terlihat dari antusias siswa dalam proses pembelajaran dan hasil membuat karangan deskripsi disetiap siklusnya meningkat. Kegiatan belajar siswa lebih komunikatif dan menyenangkan. Dalam pembelajaran menulis karangan deskripsi sebelum mengguanakan media gambar siswa terlihat pasif, kurang termotivasi, dan menganggap menulis itu menjenuhkan. Dengan penggunaan media gambar lingkungan sekitar dalam proses pembalajaran siswa menjadi lebih aktif, dapat menuangkan gagasannya dengan baik, menulis dengan kaidah penulisan yang benar, dan lebih antusias dalam mengikuti pembelajaran.

Penggunaan media gambar lingkungan sekitar dapat meningkatkan keterampilan menulis karangan deskripsi pada siswa kelas IV SDN 009 Tarue. Peningkatan keterampilan menulis pada prasiklus sebesar $5,680 \%$, siklus I sebesar 6,720\%, siklus sebesar 7,780\%.

Penelitian tindakan yang dilakukan sudah memenuhi kriteria keberhasilan yang diterapkan, yaitu siswa memperoleh nilai 70 sehingga pelaksanaan penelitian tindakan dapat disimpulkan bahwa penggunaan media gambar dapat memberikan dampak yang positif, karena dengan media gambar lingkungan sekitar dalam pembelajaran dapat meningkatkan keterampilan siswa dalam menulis karangan deskripsi.

PiJIES: Pedagogik Journal of Islamic Elementary School 


\section{DAFTAR PUSTAKA}

Abbas,Irwan, "Pappaseng: Kearifan Lokal Manusia bugis yang Terlupkan". Sosiohumaniora, vol. 15 no. 32013.

Ahmad Rohani,. 1997. Media Instruksional Edukatif, Jakarta: Rineka Cipta.

Anas Sudijono. 2007. Pengantar Statistik Pendidikan, Jakarta: Raja Grafindo Persada.

Arief S.Sadiman, dkk, 2012. Media Pendidikan: Pengertian, Pengembangan, dan Pemamfaatannya, Depok: Rajawali.

Ashar Arsyad. 2013. Media Pembelajaran. Jakarta: PT Raja Grafindo Persada. Azhar Arsyad,, 2015. Media pembelajaran, Jakarta: Rajawali.

Budiyanto. (2009). Bahasa Indonesia Menjawab Tantangan. Balai Bahasa Jawa Tengah.

Depdiknas. 2008. Peraturan Menteri Pendidikan Nasional Nomor 22 Tahun 2006 tentang Standar Isi untuk Satuan Pendidikan Dasar dan Menengah Nomor 23 tentang Standar Kompetensi Lulusan untuk Satuan Pendidikan Dasar dan Menengah Nomor 24 Tahun 2006 tentang Pelaksanaan Peraturan Mendiknas Nomor 22 dan 23. Jakarta: Depdiknas.

Fajarini, Ulfah, “Peran Kearifan Lokal dalam Pendidikan Karakter”,JurnalSosio Didaktika: Vol. 1, No. 2,2014.

Hasmira, H. (2018). Meningkatkan Keterampilan Menulis Karangan Sederhana Melalui Penggunaan Media Gambar Seri. Pedagogik Journal of Islamic Elementary School, 1(1), 47-56. https://doi.org/10.24256/pijies.v1i1.379

Idarliati, I. (2018). Peningkatan Keterampilan Menulis Karangan Deskripsi Dengan Menggunakan Media Gambar. Pedagogik Journal of Islamic Elementary School, 1(1), 57-72. https://doi.org/10.24256/pijies.v1i1.380

Nana Syaodih Sukmadinata. 2011. Landasan Psikologi proses pendidikan, Bandung: Remaja Rosdakarya.

Nurhadi. 2010. Dimensi-Dimensi dalam Belajar Bahasa Kedua, Bandung: Sinar Baru Algensindo.

Purwanto. 2007. Keterampilan Dasar Menulis. Jakarta: Universitas Terbuka.

Rustan, E. (2010). Pembelajaran Bahasa dan Sastra Daerah Berbasis Multikultural dalam Mewujudkan Pendidikan yang Berkarakter di Era Globalisasi. In Hanna, Firman, \& S. Safitri (Eds.), Kongres Internasional Bahasa-bahasa Daerah Sulawesi Tenggara (pp. 247-249). Baubau. 


\section{8 | Afifah Alawia}

Rustan, E. (2016). Analisis Penggunaan Bahasa Indonesia Laras Hukum Pada Putusan Perkara Ekonomi Syariah Pengadilan Agama Makassar. AlAmwal: Journal of Islamic Economic Law, 1(2), 166-176. https://doi.org/10.24256/alw.v1i2.278

Rustan, E., \& Subhan. (2018). Komunikasi Verbal Anak Pesisir Usia 7-8 Tahun Pada Transakasi Penjualan Produk Kebudayaan Dengan Turis mancanegara. JPUD-Jurnal Pendidikan Usia Dini, 12(1), 12-28. https://doi.org/10.21009/JPUD.121 02

Solchan dkk,. 2014. Pendidikan Bahasa Indonesia di SD, Banten: Universitas Terbuka.

Subana, dkk. Strategi Belajar Bahasa Indonesia: Berbagai Pendekatan, Metode Teknik dan Media Pengajaran, Bandung: Pustaka Setia.

Sudarwan Danim. 2011. Pengantar Kependidikan, Bandung: Alfabeta.

Syaiful Bahri Djamarah. 2002. Strategi Belajar Mengajar, (Cet. II; PT Asdi Maha Satya.

Syarif,Erman, dkk., 2016. "Integrasi Nilai Budaya Etnis Bugis Makassar dalam Proses Pembelajaran Sebagai Salah Satu Stategi Menghadapi Era Masyarakat Ekonomi Asean (MEA)",Jurnal Teori dan Praksis Pembelajaran IPS, Vol. 1, No.1.

Zulela. 2013. Pembelajaran Bahasa Indonesia Apresiasi Sastra di Sekolah Dasar, Remaja Rosdakarya.

PiJIES: Pedagogik Journal of Islamic Elementary School 